charges under a 2(c) complaint, some uniformity of price differential should be established at a level approximating the pattern of brokerage involved. 90 If the Commission chooses wisely, the per se thrust of the brokerage provision will not be rendered nugatory. That Broch has provided the occasion for re-examination of section 2(c) is clear. That Broch has forestalled unnecessary litigation in the future is not so evident.

${ }^{90}$ See the Commission's attitude as expressed in Main Fish Co., 53 F.T.C. 88, 93 (1956).

\title{
CAPITAL GAINS TAXATION OF A LEGAL LIFE TENANT WITH A LIMITED POWER TO CONSUME CORPUS
}

In United States v. De Bonchamps, 1 the Ninth Circuit Court of Appeals held that where one has a legal life estate with power to consume corpus when necessary for maintenance and support, he should be taxed on capital gains realized from the sale of any portion of the corpus as if he were fiduciary of a trust. ${ }^{2}$ The court expressly overruled its decision in United States $v$. Cooke $^{3}$ where it determined that the legal life tenant was not to be taxed on such gains at all, and in doing so, it chose to follow the course recently established by the Court of Claims in Weil v. United States. 4

\section{The Substantial OWNershIP Theory}

The government sought, unsuccessfully, in each of these three actions, to tax the life tenant in his individual capacity. In the Cooke case, the government's contention, though not entirely clear from the opinion, seems to have been that the taxpayer was given sufficient power in the testator's will to control disposition of the corpus that she ought to be considered owner thereof. ${ }^{5}$ As owner, she would clearly be taxable on capital gains realized on

1278 F.2d 127 (9th Cir. 1960).

2 Under the provisions of INT. Rev. CODE OF 1954, § 641 .

3228 F.2d 667 (9th Cir. 1955).

4180 F. Supp. 407 (Ct. Cl. 1960), cert. denied, 364 U.S. 822 (1960). There is evidence that Congress favors the rule expressed in the Weil and De Bonchamps cases. The Senate was, at the time of the De Bonchamps case, reviewing the provisions of a bill, H.R. 9662. "Under the bill, a trust will be deemed to exist for the calendar year with respect to that gain, and the person holding the legal life estate or other terminable interest will be deemed to be a fiduciary of the trust and will be required to report the gain and pay the appropriate tax." Hearings on H.R. 9662 Before the Senate Committee on Finance, 86th Cong., 2d Sess. 37 (1960). The dissent in De Bonchamps contended that the fact that the bill was up for passage implied that congressional intent could not be gleaned from the Code as it then stood, and that to read into the Code such intent would be to usurp the legislative function.

5 This, essentially, was the government's position in Ella E. Russell, 45 B.T.A. 397 (1941). In that case, the taxpayer was life beneficiary of a trust with power to order the trustees to dispose of principal when necessary for her maintenance and support. The Board held that all income from the corpus, including profits derived by sales thereof, were taxable to the beneficiary in her individual capacity by reason of her right to complete use and enjoyment. 
sale of the corpus. This contention was dismissed by the court with the observation that, since she would have been liable for conversion of principal and the capital gains in question had she recklessly disposed of them, ${ }^{6}$ she could not be regarded as owner thereof, even for the purpose of taxation.7

In De Bonchamps the government implemented the contention defeated in Cooke by relying on section 678.8 To qualify as owner of trust corpus for purposes of this Code provision, the taxpayer must have a power "exercisable solely by himself to vest the corpus or the income therefrom in himself." 9 In disposing of this contention the court was forced to consider two problems. First, since section 678 deals exclusively with trusts, its application to a nontrust case might seem questionable. The court reasoned that section 678 should be interpreted similarly to section 671 , and subpart $E$ of subchapter $\mathrm{J}$ generally. Subpart E is, in part, a codification of the decisions in Helvering $v$. Clifford ${ }^{10}$ and Mallinckrodt $v$. Nunan, ${ }^{11}$ and of the regulations which applied the doctrine of these decisions. ${ }^{12}$ The court in De Bonchamps maintained that the "Clifford Regulations" had previously been declared to have a persuasive

This result is surprising in the light of the later cases now under consideration, since under the terms of the Russell trust a court with adequate jurisdiction was required to pass upon the question of whether or not she was actually in need, before she could compel sale by the trustee.

The ownership theory was defeated in William R. Todd, 44 B.T.A. 776 (1941), another case in which a life tenant was given power by the will to consume all principal if necessary for his maintenance and support. But there the life tenant produced evidence to show that he had chosen to retain his interest only as executor of the estate and, having renounced his interest in both income and principal, was deriving no benefit from the estate.

${ }^{6}$ The taxpayer was a life tenant, with full authority under the will to "sell, transfer, and exchange said property and to reinvest the proceeds and to manage and contiol said property, reinvestments and proceeds, and to exercise all rights and power of ownership with respect thereto." The will further provided that "the proceeds and all reinvestments shall likewise be subject to a life interest in my said wife with remainder over as aforesaid." 228 F.2d at 669.

7 The dissent in Cooke urged that the taxpayer be treated as owner of the capital gain in question. This conclusion was predicated upon the seemingly erroneous notion that "income" received by a life tenant is equivalent, for tax purposes, to "income" as defined by $\$ 61(a)$ of the Internal Revenue Code. From this, it was reasoned that since the life tenant had undisputed control over income from the estate, and since capital gains are part of income as defined by $\$ 61(a)$, taxation as owner of the gain must follow. This rationale, if consistently applied, would tax a life tenant as owner of capital gains even in the absence of any power to consume corpus. The latter result is essentially that which the court refused to reach in the Weil case. See note 15 infra.

8 INT. Rev. Code OF 1954, §678.

9 Id. at $\S 678(\mathrm{a})(1)$.

10309 U.S. 331 (1940).

11146 F.2d 1 (8th Cir. 1945).

12 Treas. Reg. 118, §§ 39.22(a)-21, 22 (1945, amended 1947). 
effect in non-trust cases, 13 hence, subpart $E$ and particularly section 678 would be applicable here also. The second question was whether or not the life tenant had been given power to vest the corpus in herself. 14 Clearly she had not. She might consume it, but there was little doubt that she could not, by herself, execute conveyances which would render her owner in fee of the estate. Due to these circumstances, the court held that the taxpayers were not within the purview of section 678.15

It is evident that state law concepts of ownership affected the courts' treatment of the government's contentions. In most states, the rule is well established that a life estate is not converted to a fee by testamentary provisions giving the tenant power to consume corpus for maintenance and support.16 Capital gains are generally regarded as accruing to principal, and, subject to

13 The court referred to its own decision in Hawaiian Trust Co. v. Kanne, 172 F.2d 74 (9th Cir. 1949). This case involved a life beneficiary of a trust who had assigned part of her trust income to her son's divorced wife, in order to assist her son in meeting his support obligations imposed by a divorce decree. The decree required that payment be made until the wife should remarry, and separate payments for the children's support were to be made until the children reached majority. The executed assignments provided that the payments were to terminate on the occurrence of these events. The court held that the life beneficiary was not liable for income tax on the assigned interest since she had surrendered the substantial economic interest in the trust requisite for taxation under \$22(a) of the 1939 Code. The government contended that the case be governed by the Clifford decision, and the court agreed, basing its determination on the Supreme Court decision in Harrison v. Schaffner, 312 U.S. 579 (1941). The Schaffner case also involved assignment of trust income, and the Court in that case maintained that there was no difference, so far as the application of the Clifford rule and the Code in general is concerned, between a trust beneficiary, and an assignee of trust income assigned by the trust beneficiary. It should be noted that both the Hawaiian Trust and the Schaffner cases involved the disposition of trust income and not the tax standing of a legal life tenant. Apparently, in the eyes of the De Bonchamps court, the extension of the Clifford rules to a subsequent assignment of trust income permitted a further extension of all of subpart E to "non-trust" areas, including the legal life estate.

14 The government, it appears, did not contend that the taxpayer was owner of the trust as a result of her power to vest the income therefrom in herself. Were it possible to derive such results from $\$ 678$ it would seem that the ordinary life tenant or income beneficiary of a trust without any power to consume, would be taxed for capital gains on a similar basis. The Treasury Regulations have provided against this obvious inequity and would seemingly govern in the case under consideration: "Similarly, if a grantor or another person is treated under sections $674-678$ as an owner of a portion by reason of a power over ordinary income only, items of income allocable to corpus are not included in that portion." Treas. Reg. §1.671-3(b) (1) (1956). See also Treas. Reg. § 1.677(a)-1(g) (1956).

15 The government contended that the taxpayer was liable in her individual capacity in the Weil case also. The court considered what it thought to be the underlying premise of this theory: that the capital gain should be treated as part of the income to which the taxpayer, as life tenant, was entitled. It regarded this contention as fallacious, due primarily to the fact that the taxpayer had executed a document wherein she relinquished the right to use any part of the corpus, for any means whatsoever. It declined to assess the tax consequences which might have resulted had she failed to relinquish the right. $180 \mathrm{~F}$. Supp. at 410 n.3.

162 Powell, Real Property § 204 (1950). 
the life tenant's power to consume, belong to the remainderman.17 In states where such provisions do not exist, the government has successfully assessed life tenants as absolute owners. ${ }^{18}$ Thus, an inquiry into the amount of control over corpus is necessary only where state law provides that capital gains accrue to principal.

Assuming that such provisions exist, as they did in the cases under consideration, the question arises as to the nature of the taxpayer's "bundle of rights" which would justify taxing him as "substantial owner" of corpus, and hence of capital gains. This problem may be approached with or without reference to section 678 , but application of the section would appear to enhance the possibility of rational solution. Section 61(a) provides no answer. Absent section 678 , the concept of "substantial ownership" becomes a vague notion tempered, in these cases, by two fundamental principles: first, that Congress clearly intended to tax all capital gains, and second, that it is usually most equitable to tax the individual who receives the greatest benefit from the transaction producing the gain. A life tenant cannot execute conveyances which would render him owner in fee of the estate. In short, he cannot vest title in himself, nor can he give the property away or make testamentary disposition of it.19 These restrictions, coupled with the fact that an action for conversion will lie against the life tenant who recklessly disposes of corpus, have been deemed incompatible with the courts' notions of substantial ownership.

By contrast, section 678, as interpreted by Treasury Regulation 678(a)-1(b), establishes a readily applicable test for determining what shall be considered substantial ownership. Section 678 provides that "(a) General rule. A person other than the grantor shall be treated as the owner of any portion of a trust

17 See, e.g., Cal. Civil CoDE $\$ 730.05(2)$ cited in De Bonchamps. This section corresponds with section 3(2) of the Uniform Principal and Income Act, adopted in the following states: Ala. Code tit. 58, $\$ 77$ (1940); Ariz. Rev. Stat. ANN. § 14-1083 (1950); Colo. Rev. Stat. ANN. §57-4-3 (Supp. 1957); ConN. Gen. Stat. Rev. \$45-112 (1958); Fla. Stat. § 690.04 (1959); Ill. Rev. Stat. ch. 30, § 161 (1959); Kan. Gen. Stat. ANN. § 58-903 (Supp. 1959); Ky. Rev. Stat. § 386.210 (1959); LA. Rev. Stat. \$ 9:2092 (1950); MD. ANN. Code art. 75B, $\S 3$ (1957); N.M. Stat. ANN. § 33-5-3 (Supp. 1957); N.C. Gen. STat. § 37-3 (1950); OKLA. Stat. tit. 60, § 175.27 (1951); Ore. Rev. Stat. \$129.030 (1953); PA. Stat. tit. 20, \$ 3470.3 (Supp. 1960); Tenn. Code ANN. § 35-704 (1955); Tex. Rev. Civ. Stat. art. $7425 b-27$ (1948); UtAH CODE ANN. §22-3-3 (1953); VT. STAT. tit. 14, ch. 117, § 3303 (1947); VA. Code ANN. $\S 55-255$ (1950); W.VA. CODE ch. 36, art. 6, § 3581(8) (1931); WIs. STAT. § 231.40(3) (Supp. 1958).

${ }^{18}$ Amy H. Dupuy, 32 B.T.A. 969 (1935). This case was decided prior to the adoption by the Pennsylvania legislature of the Uniform Principal and Income Act (note 17 supra) in 1947. The board determined that the gains were part of income on the basis of the then existing common law of the state. Accord, United States v. National City Bank, 21 F. Supp. 791 (S.D.N.Y. 1937) (using New York law); Ella E. Russell, 45 B.T.A. 397 (1941) (using New Jersey law); Catherine Erswell, 1 B.T.A. 1254 (1925) (using Alabama law).

192 Powell, Real Property $\S 209$ (1950). 
with respect to which (1) such person has a power exercisable solely by himself to vest the corpus or the income therefrom in himself . . .."20 The interpretation provided by the Treasury regulation stipulates, however, that the actual power to vest title, lacking in cases involving life tenants with limited powers of consumption, is not required for taxation under the section. It provides that "section 678(a) treats a person as an owner of a trust if he has a power exercisable solely by himself to apply the income or corpus for the satisfaction of his legal obligations ...."21 It seems clear that the life tenant with unlimited power to consume would fall squarely within the provisions of this regulation, although section 678 by itself might appear not to apply. In such a case the life tenant clearly possesses the absolute power to apply corpus to the satisfaction of any legal obligation.

When the power is limited to needs of maintenance and support, however, the provisions no longer govern. This observation is predicated not upon the fact that the life tenant in such case has not a power exercisable solely by himself, 22 but upon the realization that the power which he does possess is less comprehensive than that described in the regulation. In an attempt to clarify the nature of powers which a grantor may retain and still avoid taxation as owner the Treasury regulations have imposed a limitation on taxation which would seem appropriate for application to the non-grantor situation covered by section 678. Treasury Regulation 674(b)-1(5) exempts a grantor from taxation as owner if his power to distribute corpus is "limited by a reasonably definite standard." Further, the regulation declares that "a power to distribute corpus for the education, support, maintenance, or health of the beneficiary; for his reasonable support and comfort; or to enable him to maintain his accustomed standard of living; or to meet an emergency, would be limited by a reasonably definite standard." 23 Application of the language of this regulation to cases arising under section 678 would result in nontaxability of the legal life tenant with power to invade corpus when necessary for maintenance and support.

Invocation of the section 674 regulation is warranted by several factors. While the text of section 674 refers only to grantors, the title of the regulation, as well as that of all regulations pertaining to Code sections 671-677, refers to "Grantors and Others Treated as Substantial Owners." Moreover, the arrangement of subpart E implicitly suggests that similar standards shall

20 INT. REv. CODE OF 1954, §678. (Emphasis added.)

21 Treas. Reg. $\$ 1.678(a)-1(b)$ (1956).

22 In a majority of states, a life tenant is completely free to determine when his needs of maintenance and support justify the consumption of corpus, and is required only to exercise good faith in his determination. Annot., 114 A.L.R. 946 (1938); Annot., 2 A.L.R. 1248 (1919). While the latter requirement may certainly be regarded as a restriction, it hardly alters the fact that the determination is exercisable solely by the life tenant.

${ }^{23}$ Treas. Reg. § 1.674(b)-1(5) (1956). 
apply to both. Finally, the Code evinces a stronger congressional policy to tax grantors as owners than to tax non-grantors as owners. Section 678 requires a high order of power-that which enables the holder to vest title in himself-to bring about taxation of the non-grantor. Sections 671-677 enumerate a wide range of lesser powers, any one of which is sufficient to cause taxation of a grantor. Regulation 674(b)-1(5) limits taxation of the grantor to instances of a power to invade corpus unlimited by reasonably definite external standards. It would be anomalous for this limitation not to be incorporated into section 678 , for this would mean that a grantor could safely hold a power which, if held by a non-grantor, would result in taxation.

Other sections of the 1954 Code treat the life tenant as equivalent to absolute owner of the estate. The sections dealing with depreciation, ${ }^{24}$ depletion of oil, gas, and mining resources, 25 and amortization of grain storage facilities $^{\mathbf{2 6}}$ contain specific provisions allowing deductions to the legal life tenant rather than the remainderman. It would seem, however, that the policy implicit in the deductions does not require a life tenant to be taxed on capital gains as if he were owner. ${ }^{27}$ The deductions are available only if the property is used in a trade or business or held for the production of income. They represent, at least in part, an effort by Congress to encourage replacement of old property by acquisition or construction of new. 28 If the Code had provided that such deductions be utilized only by remaindermen, serious difficulties would arise. Where the remainder is contingent, the deduction would be lost, and the desire to encourage acquisition of capital assets would be thwarted. In addition, the life tenant in possession is realistically the only one who can be encouraged to make present outlays for capital improvements.

The possible argument that the one who benefits from the depreciation deduction on the asset ought logically to be the one who pays the tax on the profit derived from subsequent sale of the asset, gives rise to substantial difficulty. In the cases under consideration, the life tenant, having the power to consume only for maintenance and support, may never consume the proceeds which represent capital gain. While it may reasonably be assumed that a tax

${ }_{24}$ INT. REv. CODE OF 1954, §167(g).

25 INT. Rev. CODE OF 1954, § 611(b)(2).

26 INT. REv. CODE OF 1954, § 169(g).

27 Prior to 1926, the revenue acts made no provision for the allocation of depreciation allowances in cases such as these. The 1926 Act provided that such deductions were to be "equitably apportioned between the life tenant and the remainderman under rules and regulations prescribed by the Commissioner with the approval of the Secretary." Revenue Act of 1926, $\$ 214($ a) (8), 44 Stat. 1983. This formula proved unworkable. See Penn v. Commissioner, 16 T.C. 1497 (1951), aff d, 199 F.2d 210, 211-12 (8th Cir. 1952), cert. denied, 344 U.S. 927 (1953); Chisolm v. United States, 85 Ct. Cl. 199, 19 F. Supp. 274 (1937). As a result, the Revenue Act of 1928 contained a clause identical to $\$ 167(\mathrm{~g})$ of the 1954 Code. Revenue Act of 1928, §23(k), 45 Stat. 800.

${ }^{23}$ See 41 A.B.A.J. 726, 728 (1955). 
on capital gain discourages, to some extent, any actual owner from disposing of assets at a particular time, it would certainly have a far greater effect upon one who never acquires the ability to consume that for which he must pay the $\operatorname{tax}^{29}$ In this sense, the tax takes the form of a penalty against certain life tenants who dispose of estate assets in order to acquire or construct new ones.

It is notable that the sale of corpus assets is, in the cases under consideration, an event which in no way reflects upon either the life tenant's intent or capacity to consume the proceeds of the sale; nor does it necessarily refiect a direct increment in the life tenant's economic worth. Whatever direct value he may derive will be realized only when and if he acquires the requisite need and intent to consume, and at that time the capital gain will have become an indistinguishable segment of the whole estate. Taxing a life tenant with a power to consume only for maintenance and support as owner must logically rest upon the presupposition that such needs will arise. It seems clear that the automatic invocation of such presuppositions on the occurrence of a sale of assets is logically unsupportable and, in some cases, grossly unfair.

\section{THE FidUCIARY THEORY}

The government's alternative theory-that the life tenant is taxable on the capital gains as fiduciary of a trust under section $641^{30}$-was defeated in the Cooke case but prevailed in Weil and De Bonchamps. The general problems involved in the application of trust provisions to a legal life estate are encountered under this theory as well as in the application of section 678. In addition, the courts were confronted with the problem of adapting to legal life tenants, provisions designed to govern the taxation of trustees. In attempting to resolve these difficulties, the court in Weil mentioned again that there is a "legislative design to reach all gain constitutionally taxable unless specifically

29 The deterrent effect of capital gains taxation upon replacement and acquisition of assets would, of course, be less noticeable in situations where the present assets cease producing income or the life tenant seeks more income than the particular assets are capable of producing. In these cases, the sale of assets is prompted largely by present needs. While the capital gains tax will tend to discourage disposal, it will certainly have less effect here than in those situations where the disposition is made in order to acquire ownership of the gain itself.

30 INr. Rev. CODE of 1954, § 641: "(a) ApPLICATION of TAX.-The taxes imposed by this chapter on individuals shall apply to the taxable income of estates or of any kind of property held in trust, including-(1) income accumulated in trust for the benefit of unborn or unascertained persons or persons with contingent interests, and income accumulated or held for future distribution under the terms of the will or trust; (2) income which is to be distributed currently by the fiduciary to the beneficiaries, and income collected by a guardian of an infant which is to be held or distributed as the court may direct; (3) income received by estates of deceased persons during the period of administration or settlement of the estate; and (4) income which, in the discretion of the fiduciary, may be either distributed to the beneficiaries or accumulated. "(b) COMPUTATION AND PAYMENT.-The taxable income of an estate or trust shall be computed in the same manner as in the case of an individual, except as otherwise provided in this part. The tax shall be computed on such taxable income and shall be paid by the fiduciary." 
excluded." 31 More specifically, the court observed that previous cases 32 had utilized similar sections of the revenue acts ${ }^{33}$ in assessing individuals not qualifying, technically, as trustees. In each of the cases cited, the individual held assets pending final court determination of the proper manner for distribution. Aside from this, the taxpayers had no interest in the property. ${ }^{34}$ The similarity between these individuals and a life tenant, particularly one with power to consume corpus, seems remote.

A further argument for application of section 641 to taxpayers who were not fiduciaries, appeared both in Weil and in De Bonchamps. The courts observed that, had the life interest been given to a technical trustee to be administered by him for the benefit of the life beneficiary, gains would clearly have been taxable to the trustee as fiduciary. The courts then referred to the $R e$ statement of Property, 35 to the effect that the relations between the trustee of a life interest only, and the owners of succeeding interests are identical to those existing between legal life tenants and remaindermen. Basically, the Restatement provides that where one is given a life estate in personal property, there is an implied power to dispose of the corpus for purposes of reinvestment, and that one possessing such power ought to be required to give security to the holder of the succeeding interest against mismanagement or, in lieu thereof, to turn over the assets to a judicially determined trustee. Where there is an unrestricted power to consume, the Institute has stipulated that the provision requiring security is inapplicable. ${ }^{36}$ In addition, where the power is limited, "as for the support of the owner of the present life interest," the provision is inapplicable unless the prior conduct of the life tenant is such as would create a reasonable apprehension of harm to a future interest. ${ }^{37}$

$31180 \mathrm{~F}$. Supp. at 410 . The court quoted from General Am. Investors Co. v. Commissioner, 348 U.S. 434, 436 (1955).

32 Commissioner v. Owens, 78 F.2d 768 (10th Cir. 1935); Hart v. Commissioner, 54 F.2d 848 (1st Cir. 1932); Ferguson v. Fortsmann, 25 F.2d 47 (3rd Cir. 1928).

33 Owens (Revenue Act of 1916, ch. 463, §2(b), 39 Stat. 757; Revenue Act of 1918, ch. 18, $\$ 219,40$ Stat. 1071; Revenue Act of 1921, ch. 136, § 219, 42 Stat. 246); Hart (Revenue Act of 1926, ch. 27, $\S \S 219$ (a)(1), 219(b), 44 Stat. 32-33); Forstmann (Revenue Act of 1918, supra; Revenue Act of 1921, supra).

${ }^{34}$ In Forstmann the court referred to a corporation which retained dividends pending final determination of stock ownership as a fiduciary, holding such dividends in trust. Hart attributed a similar status to the receiver of a corporation to whom securities were entrusted by stockholders pending determination of ownership. In Owens, the government was suing an Indian allottee's heirs to cancel allotment and, pending the outcome, a receiver was appointed to lease the land for oil and gas extraction. The receiver was held to be a fiduciary for purposes of taxation.

35 Restatement, Property \& 202, comment $d$ (1936).

36 RESTATEMENT, PROPERTY \$202, comment $e$ (1936).

${ }^{37} \mathrm{Ibid}$. It should also be noted that the Restatement provision is applicable "only in the absence of a manifestation of a contrary intent in the instrument creating the life interest." This limitation would clearly prevent the application of the provision to either the Cooke or the Weil case. In the former case the will provided that the life tenant "shall not be 
Thus, while the analogy drawn by the Institute between the holder of a legal life estate in personal property and a trustee of a life interest is reasonable, its application to the life tenant with power to consume seems unwarranted. Whatever the justification, however, the courts in De Bonchamps and Weil gave considerable credence to the analogy. The basic problem in the application of section 641 was thus overcome.

It is evident that the court in Cooke would have reached a similar conclusion were it not for the existence of a Treasury regulation which the court felt did not permit an extension of section 641 to any non-trust area. ${ }^{38}$ The refusal in Cooke to extend the provisions of [the predecessor of section 641] to the non-trust area was based upon a literal interpretation of Regulation 118, $\$ 39.3797$ (1953). This regulation provided that 'the term 'trust' as used in the Internal Revenue Code, refers to an ordinary trust, namely, one created by will or by declaration of the grantor, the trustees of which take title to the property for the purpose of protecting or conserving it as customarily required under ordinary rules applied in chancery and probate courts." Since the will in that case provided that the life tenant was to take without impeachment for waste and, further, that no person purchasing from or otherwise dealing with the life tenant was to be liable to "see to the application by [the life tenant] of the proceeds of any sale or to the propriety of any other action taken by the [life tenant]," 39 the court reasoned that she did not take title to the property for the purpose of "conserving it as customarily required." As an example of a power held by the life tenant which would be inconsistent with the ordinary powers of a trustee, the court observed that if the life tenant chose to convey the corpus by gift to a charitable corporation, the latter could not be forced to return it.

In De Bonchamps, the court was skeptical of the Cooke interpretation of Regulation 39.3797 since it would exclude income from taxation, an intent rarely to be derived from Treasury regulations. Rather, the court chose to accept the government's interpretation of the regulation: that it was intended to exclude business trusts from this area, thereby confining them to the cor-

required to give any security for the safekeeping or preservation of the corpus." $228 \mathrm{~F} .2 \mathrm{~d}$ at 669 . In the latter case the will provided that "she shall also have the right, in her absolute discretion, to sell, mortgage, pledge or dispose of all or any part of said estate, real, personal or mixed, for such amount and on such terms and in any manner that she may see fit." 180 F. Supp. at 409.

38 It would seem that the same argument might have been utilized to defeat taxation under section 678 had that section been invoked in Cooke.

39228 F.2d at 669 . In the De Bonchamps case, the power to invade corpus was limited to requirements of "maintenance and comfort during her life without any restriction" in the first of the wills under consideration. The other was identical to the first except that the testator included a provision to the effect that "it is my wish and intention to have my wife enjoy the full use of said corpus and income during her natural life" and that the remainderman "shall have and take what is left thereof at the time of her death." 278 F.2d at 128-29. 
poration classification. 40 The court then reiterated the notion that section 641 was intended to apply to relationships "clothed with the characteristics of a trust."41

Courts have occasionally referred to the life tenant as quasi-trustee;42 but it is generally believed that "notwithstanding ... [some] slight similarities [between trustees and life tenants], life tenants are held by the better reasoned cases not to be trustees in any strict sense." 43 It is generally held, for example, that life tenants cannot be required to give security against misappropriation of corpus, and this is particularly true if they have power to consume. 44 Common law distinctions such as these seem far less important here, however, than they did in relation to the ownership theory.

The underlying policy of section 641 provides the most satisfactory, and perhaps the only adequate, support for the fiduciary theory. Section 641 may easily be viewed as a provision enabling the government to tax the income from property to which no person presently has absolute ownership. Essentially, it provides that the person exercising control over the corpus should pay the tax on all income accruing thereto which is not to be and is not currently distributed to an income beneficiary. There is little doubt that the tax-

40 In Security-First Nat'l Bank v. United States, 181 F. Supp. 911 (S.D. Cal. 1960), the court disposed of the argument used in the Cooke case in more depth. It observed that paragraph 1 of Regulation 39.3797 (1953), setting forth the object of the regulation itself, stated, unequivocally, that the Code provides its own standards of classification and is not bound by local law. Further, the regulation states: "Thus, a trust may be classed as a trust or as an association (and, therefore, as a corporation), depending upon its nature of its activities." It seems clear that, as the court states, the regulation was intended to exclude particular admitted trust relationships from taxation under the provisions of $\S 161$ (predecessor to $\$ 641$ ) rather than excluding all relationships which did not qualify as technical trusts under local law.

${ }^{41}$ It is perhaps significant that the major cases under consideration all cite the same three cases for this point. In Security-First Nat'l Bank v. United States, supra note 40, they appear once again. Here, however, the case of Buckley v. Commissioner, 66 F.2d 394 (2d Cir. 1933) was added to bolster the analogy. In that case, following condemnation of an estate by a city, the life tenant chose to take a portion of the award. The balance of the award was placed in the custody of a city official to hold for the remaindermen, and it was held that the official was required to file a tax return on the earnings of the funds, as fiduciary. The court in Buckley refers to the sum held by the official as the "trust fund" and refers to the official as "an officer of the State court, ... . holding a fund for investment, accumulation, and distribution subject to the orders of the court and entirely for the benefit of the remainderman." Id. at 396-97. It would seem that the similarity between this individual and a life tenant given power to invade corpus is scant. The analogy is tenuous, yet it is all that the courts have relied upon to tax a life tenant under $\$ 641(\mathrm{a})$.

42 Buder v. Franz, 27 F.2d 101 (8th Cir. 1928); Keefe v. Keefe, 257 N.Y. 604, 178 N.E. 814 (1931); Mallett v. Hall, 129 Me. 148, 150 Atl. 531 (1930).

431 Bogert, Trusts \& TRustees 217 (1951). See, e.g., In re Gile's Estate, 95 N.H. 270, 61 Atl.2d 798 (1948); In re Gillett's Estate, 130 Pa. Super. 309. 197 Atl. 517 (1938). In these cases the grant to the life tenant included the power to consume corpus.

4431 C.J.S. Estates $\$ 59$ (1942). But see Restatement, Property \$ 202 (1936) discussed in text accompanying note 35 supra. 
able income of "any kind of property held in trust" includes capital gains realized on the sale of such property. 45 In the De Bonchamps situation, there is also an ascertainable corpus and no person able to exercise rights of absolute ownership over it. Here, as in the trust situation, the property is controlled and managed by an individual. The policy implicit in section 641 would seem, therefore, to justify taxation as a fiduciary of the legal life tenant with power to consume for needs of maintenance and support.

\section{TAX EFFECT OF THE Two THEORIES}

The life tenant, if taxed as owner of a trust under section 678 , would be forced to include the capital gain in his individual return as if the "trust" did not, in fact, exist, while if taxed as fiduciary, he would be entitled to file a separate return covering all income of the trust. 46 The disparity between the respective amounts of taxes payable could be significant, depending upon the size of the gain 47 and the life tenant's individual income. Where the gain is relatively small, and the life tenant is in a lower income bracket, his tax on the gain, if he were treated as owner, would be computed by applying a rate determined by his individual income plus half the value of the gain to $50 \%$ of the gain. 48

45 In short, as the first sentence of $\$ 641(\mathrm{~b})$ intimates, the trust or estate shall be essentially regarded as an individual for purposes of taxation.

46 If treated as fiduciary, the life tenant would be required to file a separate form 1041 return under the rules prescribed by Code section 6012 and Treas. Reg. $\$ 1.6012-3$ (1954). This return is required regardless of whether or not capital gains were realized for that year, provided the "trust has for the taxable year any taxable income, or has for the taxable year gross income of $\$ 600$ or more regardless of the amount of taxable income." Treas. Reg. $\S 1.6012-3$ (a) (1954).

In computing taxable income, he would be forced to include all income, including capital gains, earned by the assets during the taxable year. From this, he would first deduct the income which does not accrue to principal, since it is an amount "required to be distributed currently" to himself under the terms of section 661 (a). The amount actually paid to the life tenant as an individual would be fully deductible except to the extent that such amount exceeded the distributable net income. The latter amount includes all ordinary income plus any amount of capital gain actually distributed.

If no capital gains are realized for the taxable year, the requirement that a fiduciary return be filed would seem to impose upon the taxpayer the burden of going through empty motions, i.e., declaring all income received by the "trust" and deducting the same amount as distributed to himself under section 661(a). The added burden upon the Internal Revenue Service of processing two returns instead of one might prove substantial. The requirement may be desirable, however, in that it will presumably overcome the incidence of unreported gains when and if they are realized.

Fiduciaries are also required, under Section 6903 of the Code, to give notice to the district director of the fact that they are fiduciaries, and disclose the entity for which they will act as such. In addition, Treas. Reg. $\$ 1.6012-3$ prescribes that the fiduciary submit a copy of the will in which the "trust" was created if, in any taxable year, the gross income of the trust exceeds $\$ 5000$.

47 It will be assumed for the purpose of computing tax effects that the capital gain is the sole component of the trust's taxable income. Only if trust receipts which accrue to principal, under the governing instrument or state law, are treated for tax purposes as ordinary income will anything other than capital gains be included in taxable income.

48 INT. REV. CODE OF 1954, §§ 1201(b), 1202. 
If the life tenant were taxed as fiduciary, the tax on the gain would be computed in a similar fashion with half of the total value of the gain furnishing the basis for the rate determination. It is obvious that, except for the case in which the life tenant has no individual income for the taxable year, the rate at which the gain will be taxed would be higher if the life tenant were taxed as owner than if he were taxed as fiduciary. On the continued assumption of a relatively small capital gain, the disparity in tax payable would grow as the life tenant's individual income increased, up to the point at which normal taxation of $50 \%$ of the gain equals $25 \%$ of the total gain, the maximum rate of tax for capital gains. In contrast, where the capital gain itself is sufficiently large to invoke the flat $25 \%$ rate of taxation- $\$ 82,731$ at present-the tax paid under the fiduciary theory would be the same as that paid under the ownership theory, regardless of the life tenant's individual income.

Where a capital loss is incurred, the effect on net tax payable could be substantial. Since capital losses are utilized to offset capital gains plus $\$ 1000$ of ordinary income, 49 it would be to the government's advantage to tax the life tenant in his fiduciary capacity, thereby preventing the use of such losses to offset supplementary gains and income acquired without reference to the estate. 50

Assuming he were taxed as fiduciary of a trust in which he had power to consume corpus for purposes only of maintenance and support, there is a question as to whether the life tenant could reimburse himself from principal. Whereas the technical trustee is entitled to reimbursement for taxes out of trust corpus, ${ }^{51}$ the life tenant is generally not allowed to recover amounts expended for taxes on the estate assets. ${ }^{52}$ While it would seem unfair to tax him as a trustee, and then prevent the reimbursement to which trustees are entitled, there is no guarantee that state courts would accept the trust analogy adopted, for purposes of taxation, by the federal courts. There is the chance that they would, however, and on this basis alone the holder of a life estate would undoubtedly prefer taxation in a fiduciary capacity. .53

49 INT. Rev. CODE OF 1954, §1211(b).

so In addition, if taxed as fiduciary, the life tenant could claim the $\$ 300$ trust deduction provided for in $\$ 642(b)$.

Although the present discussion has been limited to the treatment of capital gains and losses, there would, of course, be disparity in the net tax payable by a life tenant as owner or as fiduciary, with respect to ordinary and short term gains and losses accruing to principal.

51 Restatement, Trusts $\$ 244$ (1935). See In re King's Estate, 130 Misc. 296, 244 N.Y. Supp. 283 (1927); Industrial Trust Co. v. Winslow, 60 R.I. 61, 197 Atl. 185 (1938).

52 Cf. Spring v. Hollander, 261 Mass. 373, 158 N.E. 791 (1927).

53 The treatment of section 212 expenses-those incurred in the production of income -may pose problems. The life tenant might take a deduction for such expenses in two distinct ways; it is not immediately apparent which will be approved by the Treasury. First, the life tenant, acting as fiduciary, could distribute all income to himself without declaring any expenses on his trust return. Subsequently, he would seemingly be entitled to claim the deduction on his individual return, since, in spite of the fact that the property is held in 


\section{CONCLUSION}

The courts have found reason to believe that Congress intended that the life tenant be taxed as fiduciary of a trust. It is perhaps more accurate to say that Congress does not intend that capital gain shall go untaxed.54 This intent is manifested both in the legal life estate situation and in the case of a life tenant with an unlimited power to consume. It would seem desirable, however, that a distinction be retained. In those states where capital gains accrue to principal, and the life tenant has no power to consume such principal, it would be unjust to tax him as if he were owner of such gains. If the gain is to be taxed,55 it would seemingly be fairer to assess the corpus itself and allow the life tenant, acting as fiduciary, to attempt to extract the assessment from the corpus assets. On the other hand, where there is an unlimited power to consume and dispose, it would be reasonable to tax him as owner on the possibility that he will assume complete ownership of the gains. It is not unreasonable to suppose that, if circumstances so demand, the life tenant with such powers will extract payment from the corpus by consuming at least the amount

life tenancy, such expenses would seem to have been incurred in the management of "property held for the production of income," under section 212. Under the second method, the life tenant qua fiduciary would again distribute all income to himself, but would deduct, in the trust return, section 212 expenses before computing section 651 deductions allowed for sums distributed to beneficiaries. On his individual return, the life tenant would declare, as income received from the trust, the amount actually received minus the expenses deducted on the trust return. The difficulty with this method is that under the laws of most states, the life tenant cannot obtain compensation from the estate corpus for expenses incurred in managing the estate. 31 C.J.S. Estates $\S 49$ (1942). Therefore, it would appear difficult to view these expenses as having been incurred by the estate, for the purpose of section 212 .

While in the majority of situations the end results of the two methods would be identical, several situations would produce significant differences. For example, where trust receipts for a given year consist entirely of non-distributable capital gains, the first method would allow the life tenant to use section 212 expenses to offset income from other sources, while under the second method, the life tenant would be entitled only to use the deductions to offset capital gains on his trust return. Where neither ordinary income nor capital gain is received by the "trust," the first method would allow the life tenant to use the deduction to offset income from other sources, while under the second method, the deduction would be lost.

54 The Senate Finance Committee hearing contained the following colloquy:

"Mr. Glassmann: ... I might say, this later decision by the ninth circuit [De Bonchamps] as well as decisions by the Court of Claims [Weil] and district courts of California [Security-First Nat'], seem to have removed the need for corrective legislation contained in section 101 of the bill [H.R. 9662], at least for the present time.

Senator Frear (chairman): The Senator from Utah.

Senator Bennett: What you are telling us then, is that the effect of the bill would have been the same as the effect of the De Bonchamps decision?

Mr. Glassmann: The decision of the court in the De Bonchamps case seems to be pretty much in line with what the bill would provide, and it would seem unnecessary to have the legislation passed with the case law in its present posture." Hearings on H.R.9662 Before the Senate Finance Committee, 86th Cong., 2d Sess. 74 (1960).

55 Carrying over the basis of the disposed asset to the acquired asset is not a plausible solution, since the property may be sold for cash only. 
which he has been required to pay in taxes. Finally, where there is a power to consume only for purposes of maintenance and support, the life tenant should pay the tax in a fiduciary capacity. When the individual is in a position where he must rely on consumption of corpus for his maintenance and support, taxing him as owner of capital gains would tend to increase his needs. In order to satisfy them he would be forced to consume corpus assets in such amount as to offset the cost incurred by the tax assessment. This method could produce additional hardships resulting from delays between time of payment of the tax and acquisition of liquidated corpus assets. Where the life tenant does not rely on corpus for maintenance and support, taxing him as owner would be unjust, since his position would not enable him to acquire, absolutely, the gain for which he would be taxed.

\section{ASSERTION OF THE ATTORNEY-CLIENT PRIVILEGE TO PROTECT THE CLIENT'S IDENTITY}

The attorney-client privilege, which prevents disclosure of statements made confidentially to an attorney, 1 has been limited by the rule that the client's identity falls outside the scope of the privilege. ${ }^{2}$ This judicially imposed limitation has recently been subjected to close scrutiny. In three recent cases the privilege has been invoked to protect the identity of clients. ${ }^{3}$ These cases reflect an emphasis on the underlying purpose of the attoney-client privilege and a tendency to reject the rule, that the client's identity is not privileged, when it conflicts with that purpose. It is the effect of these cases on the general rule which constitutes the principal topic of this note.

The attorney-client privilege, stated generally, provides that confidential statements, communicated in the course of a professonal relationship between an attorney and his client, may not be divulged by the attorney without the client's consent. ${ }^{4}$ The attorney-client privilege formerly was considered a matter of the attorney's honor; but it is now considered to be the privilege of the client. 5 Modern justifications for the attorney-client privilege are based on social policy. The most frequently stated justification is that the privilege

18 WiGMORE, EVIDENCE $\$ 2290$ (3d ed. 1940).

2 E.g., United States v. Pape, 144 F.2d 778 (2d Cir. 1944); Goddard v. United States 131 F.2d 220 (5th Cir. 1942); People ex rel. Vogelstein v. Warden, 150 Misc. 714, 270 N.Y. Supp. 362 (Sup. Ct. 1934), aff'd. mem., 242 App. Div. 611, 271 N.Y. Supp. 1059 (1934); Annot., 114 A.L.R. 1321 (1938).

3 Baird v. Koerner, 279 F.2d 623 (9th Cir. 1960), 13 AlA. L. Rev. 196 (1960), 47 VA. L. REv. 126 (1961). Ex parte Enzor, 270 Ala. 254, 117 So. 2d 361 (1960); In re Kaplan 8 N.Y.2d 214, 168 N.E.2d 660, 203 N.Y.S.2d 836 (1960).

497 C.J.S. Witnesses $\$ 276$ (1957). For a more detailed statement of the general rule see 8 WIGMORE, EvidENCE $\$ 2292$ (3d ed. 1940). The attorney-client privilege has been codified in many jurisdictions in essentially its common law form. Id. at 558 .

58 WIGMORE, EVIDENCE $\$ 2290$ (3d. ed. 1940). 